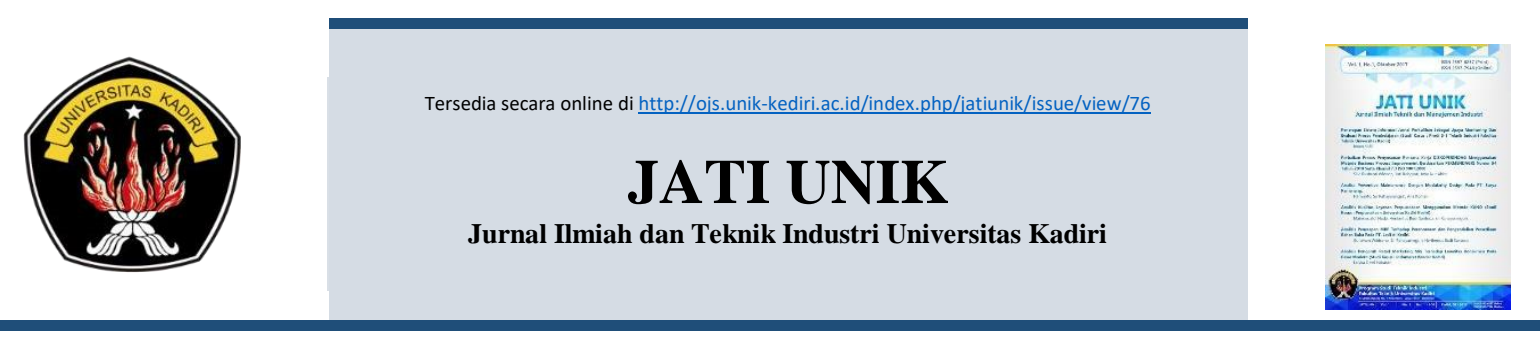

\title{
Hubungan Stres Kerja dan Cedera Otot dengan Produktivitas Tenaga Kerja pada Industri Tahu
}

\author{
Sri Rahayuningsih ${ }^{* 1}$ \\ ${ }^{1}$ Program Studi Teknik Industri, Fakultas Teknik, Universitas Kadiri \\ Email: nuning@unik-kediri.ac.id ${ }^{1}$
}

\section{InformasiArtikel}

Riwayat Artikel :

Received : 09 - Maret -2020

Revised : 13 - Maret-2020

Accepted : 28 - April - 2020

\section{Kata kunci :}

Asymp.Sig

Chi-Square

Job Stress

Muscle Injuries

Purposive sampling

\begin{abstract}
In the activities of the tofu industry will be associated with muscle injury and work stress on labor productivity. In this case needed a way to find out how big the relationship between work stress with work productivity and muscle injury with worker productivity in the tofu industry. Research conducted with the population is tofu industry in Kediri Regency using non-probability sampling with purposive sampling technique. From this sample, 17 respondents were identified as having experienced work stress and injuries due to ordering excess tofu with duration < 14 days and age of workers > 20 years to $<80$ years. Distributing questionnaires to respondents was then carried out the relationship test that hypothesis on work stress have a relationship with productivity that is worth Asymp. The work stress variable of 0,000 has reached the value of $0,000<0.05$ and the productivity variable is $0.002<$ 0.05. Whereas in muscle injury with work productivity Asymp value. The work is Chi-Square Test. From these tests the results obtained in accordance with the stress variable of 0,000 has reached the value of $0,000<0.05$ and the productivity variable is $0.002<0.05$.
\end{abstract}

Untuk melakukan sitasi pada penelitian ini dengan format:

Sri Rahayuningsih, (2020). Hubungan Stres Kerja dan Cedera Otot dengan Produktivitas Tenaga kerja pada Industri Tahu. JATI UNIK : Jurnal Ilmiah Teknik dan Manajemen Industri Universitas Kadiri, volume 3 (2), 120 - 132.

\begin{abstract}
A b s t r a k
Di dalam kegiatan industri tahu akan berkaitan dengan cedera otot dan stress kerja terhadap produktivitas tenaga kerjanya. Dalam hal ini diperlukan cara untuk mengetahui seberapa besar hubungan pada stress kerja dengan produktivitas kerja dan cedera otot dengan produktivitas pekerja pada industri tahu tersebut. Dilakukan penelitian dengan populasi adalah industri tahu di Kabupaten Kediri menggunakan nonprobability sampling dengan teknik purposive sampling. Dari sampel tersebut didapatkan responden sejumlah 17 orang dengan kriteria pernah mengalami stress kerja dan cedera akibat pemesanan tahu yang berlebih dengan durasi $<14$ hari dan usia pekerja $>20$ tahun sampai $<80$ tahun. Dilakukan penyebaran kuisioner kepada responden kemudian dilakukan uji hubungan yaitu Uji Chi-Square. Dari uji tersebut didapatkan hasil sesuai dengan hipotesis pada stress kerja
\end{abstract}


memiliki hubungan dengan produktivitas yang bernilai Asymp. Sig variabel stress kerja sebesar 0,000 sudah mencapai nilai $0,000<0,05$ dan variabel produktivitas sebesar $0,002<$ 0,05 . Sedangkan pada cedera otot dengan produktivitas kerja nilai Asymp. Sig variabel stress kerja sebesar 0,000 sudah mencapai nilai $0,000<0,05$ dan variabel produktivitas sebesar $0,002<0,05$.

\section{Pendahuluan}

Kondisi perekonomian negara Indonesia sedang mengalami perkembangan saat ini, perkembangan tersebut disebabkan meningkatkan berdirinya kelompok-kelompok usaha yang berada pada daerah-daerah diseluruh wilayah Indonesia. Kelompok-kelompok usaha tersebut diasumsikan yaitu usaha kecil, mikro dan menengah pada tahun 2017 memiliki jumlah unit sebanyak 62,9 juta unit dengan kriteria berdasarkan aset yang dimiliki [1], [2]:

Tabel 1. Usaha Berdasarkan Kriteria

\begin{tabular}{ccc}
\hline Jenis usaha & \multicolumn{2}{c}{ Kriteria } \\
\hline & Aset $(\mathrm{Rp})$ & Omzet $(\mathrm{Rp})$ \\
\hline & (tidak termasuk tanah dan bangunan) & (asumsi 1 tahun) \\
\hline Mikro & $\leq 50$ juta & $>300$ juta \\
\hline Kecil & $>50$ juta -500 juta & $>300$ juta -2.5 miliar \\
\hline Menengah & $>500$ juta -10 miliar & $>2,5$ miliar -50 miliar \\
\hline & (Sumber : Undang-Undang No. 20/ $2008[3])$
\end{tabular}

Dengan adanya usaha kecil, mikro dan menengah (UMKM) diharapkan dapat mengurangi angka pengangguran. Didalam aktivitas yang dilakukan oleh tenaga kerja pada usaha kecil, mikro dan menengah (UMKM) sangat rentang timbulnya tekanan didalam bekerja [4]. Hal tersebut disebabkan karena pada UMKM jika terjadi pemesanan dari konsumen yang berlebih, tenaga kerja dan pemilik usaha akan bekerja lebih ekstra dan melakukan kegiatan lembur kerja. Kegiatan tersebut akan menimbulkan efek-efek negatif jika tidak dilakukan dengan benar. Efek yang terutama timbul adalah menurunnya tingkat produktivitas para tenaga kerja, selain itu timbulnya stress kerja dan akan berdampak pada fisik tenaga kerja [5]. Dampak yang terjadi pada fisik pekerja yaitu timbulnya cedera otot pada area tubuh yang digunakan untuk bekerja.

Usaha kecil, mikro dan menengah yang saat ini menjadi daya tarik di Kediri yaitu industri kecil tahu. Pada industri tahu, memiliki citra karena sebagai makanan khas Kediri dan sebagai oleh-oleh bagi pendatang yang ingin ke Kediri. Industri tahu di Kediri tersebar mulai dari Kabupaten Kediri dan Kota Kediri. Industri tahu memiliki tahapan proses yang panjang dan beban yang ditanggung tenaga kerja sangat berat yang berpotensi pada kecelakaan kerja [6]. Di dalam kecelakaan kerja bisa menyebabkan serangan fisik dan psikis. Pada fisik adalah cedera pada area tubuh tertentu, sedangkan fisik dapat menimbulkan tekanan kerja dan timbul stress kerja [7]. Dalam kegiatan yang dilakukan pada proses pembuatan tahu dapat memberikan dampak tekanan berlebih yaitu meningkatnya stress kerja yang disebabkan pemesanan dari konsumen yang diluar produksi sehari-hari, kemudian dengan meningkatnya stress kerja akan berdampak pada tenaga kerja yaitu antara stress yang besifat membangun atau yang bersifat negatif [8]. Jika stress tersebut dapat 
membangun akan memberikan pengaruh produktivitas pada tenaga kerja tentang peningkatan performa bekerja, adaptasi dalam melakukan aktivitas jika pemesanan berlebih [9]. Sedangkan jika stress kerja dianggap negatif akan memberikan efek terjadinya penurunan produktivitas, keadaan sakit dan adanya cedera otot pada area tubuh yang digunakan untuk bekerja [10], [11].

Stress kerja yang terjadi memiliki sumber penyebabnya yaitu pada kondisi pekerjaan terkait dengan menurunnya motivadi didalam bekerja, aktivitas konsentrasi yang sulit, kemudian didalam area kerja yang tidak memiliki kenyaman serta kondisi ruangan yang pengap, tidak bersih dan sirkulasi udara yang kurang memadai [12], [13]. Sedangkan pada stress kerja yang disebabkan karena peran adalah peran yang dimiliki pada perusahaan tidak sesuai dengan harapan, sering adanya konflik, kemudian peran yang diberikan tidak sesuai dengan bidang yang dimiliki oleh tenaga kerja. Berbeda dengan faktor interpersonal, pada faktor ini stress ditinjau dari sistem dukungan pada sosial yang buruk, adanya persaingan politik, kurangnya manajemen yang diatur pada perusahaan terhadap karyawan [14]. Dari faktor yang dilami oleh warga negara Indonesia terkait stress kerja faktor tertinggi adalah pekerjaan yang menumpuk, karena disebabkan oleh manajemen waktu untuk mengatur waktu yang kurang baik. Didalam gejala yang timbul karena adanya stress didalam bekerja yaitu perasaan tegang, mudah tersinggung, cepat menyerah dan depresi kemudian rasa untuk percaya diri pada bidang pekerjaanya menurun [15]. Tidak hanya itu, secara fisik stress kerja juga memiliki dampak antara lain tekanan darah tidak stabil, timbulnya sakit magh, imun tubuh menurun dan sering terjadi gangguan pada tidur. Sedangkan pada perilaku yang dapat dilihat adalah sering menunda pekerjaan, prestasi dan produktivitas menurun, aktivitas makan yang tidak normal sebagai pelampiasan. Oleh karena itu, berkaitan dengan tenaga kerja yang berprofesi sebagai pembuat tahu perlu mengetahui penyebab-penyebab ketika tubuh dan apa yang dirasakan oleh tubuhnya tidak seperti biasanya [16], [17]. Tidak hanya itu, untuk masalah selanjutnya adalah cedera otot yang terjadi pada tenaga kerja pembuatan tahu antara lain pada bagian tubuh tangan, punggung, pinggang [18], [19]. Tingkat stress tersebut memiliki kaitan dengan hasil informasi dari kompasiana.com pada tahun 2015 , tingkat stress terjadi pada penyebab pekerjaan yang menumpuk dengan prosentase $43,5 \%$ lebih besar dari pada tekanan ekonomi, persoalan keluarga dan lain-lain. Pada aktivitas pekerjaan menumpuk sangat memberikan pengaruh besar bagi warga Indonesia, dikarenakan dalam psikis mungkin belum siap menerima tekanan beban kerja yang besar, sedangkan secara fisik pekerjaan tersebut belum sesuai dengan porsi yang dilakukan setiap harinya. Oleh karena itu, potensi pekerjaan menumpuk memberikan sumbangan tingkat stress paling besar. Karena tingkat stress pada pekerjaan menumpuk, akan terbawa diwaktu -waktu yang seharusnya masalah tersebut tidak perlu dipikirkan ketika sudah berada diluar jam kerja. Dilihat dari tekanan ekonomi yang memiliki potensi sebesar 20,4\% dikarenakan Indonesia masih negara berkembang, mayoritas warga Indonesia mengalami tekanan ekonomi dalam hal memberikan pendidikan kepada anak, memberikan asupan konsumsi makan untuk hidup bagi keluarga yang masih berkecukupan sehingga perlu melakukan kerja keras agar dapat memberikan penghidupan yang layak bagi keluarganya. Disisi lain, mahalnya harga untuk membeli kebutuhan pokok juga berimbas pada tingkat stress yang dialaminya. Kemudian persoalan keluarga, akan memberikan pengaruh bagi tingkat stress dengan prosentase sebesar $28,7 \%$ dikarenakan penyebab ini dapat memberikan dampak 
terhadap aktivitas bekerja yang tidak akan fokus bekerja karena masih memikirkan masalah keluarga, dan sisanya yaitu 7,4\% penyebabnya adalah lain-lain yang belum diketahui secara pasti. Semakin tinggi tingkat stress seseorang, akan memberikan dampak negatif bagi kehidupannya dan akan mempersulit cara berpikir disaat bekerja, karena didalam bekerja diperlukan kecepatan dalam melakukan pekerjaan agar produktivitas meningkat.

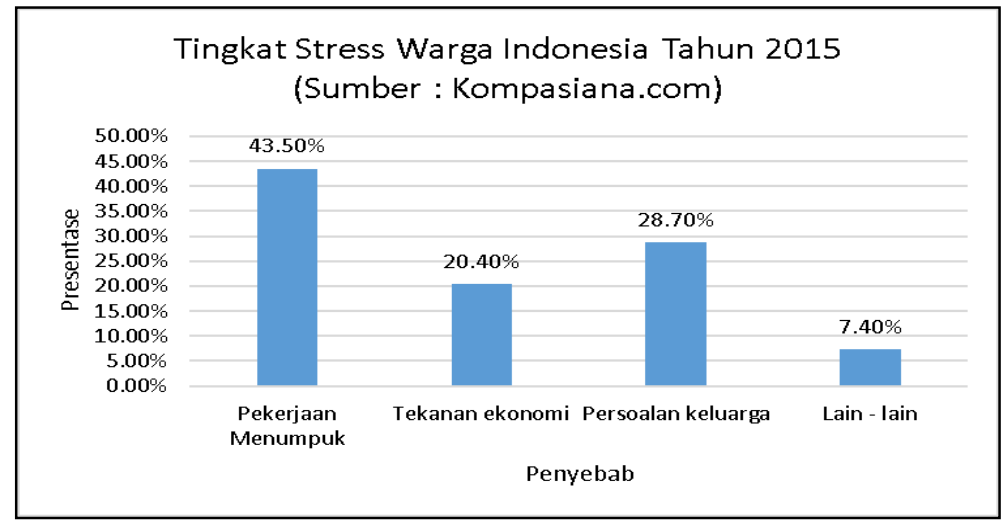

Gambar 1. Tingkat Stress Kerja Warga Indonesia Tahun 2015

Cedera otot tersebut dirasakan oleh tenaga kerja jika sudah mengalami tingkat yang parah, sampai tubuh bagian tertentu terasa sakit dan sulit untuk digerakkan [20], [21]. Sehingga, pekerja tidak dapat melakukan gerakan saat itu, karena jika dilakukan gerakan pada area yang sakit, akan memperparah cedera otot yang terjadi. Dalam gejala awal pada cedera otot, tenaga kerja menganggap hal tersebut sebagai kelelahan dan bisa sembuh ketika digunakan untuk istirahat [22]. Tetapi, dalam kasusnya tidak seperti itu, dikarenakan gejala yang timbul sudah terlalu lama dan dibiarkan begitu saja, tanpa ada pemberian obat atau dilakukan pemeriksaan.Akibatnya, cedera otot tersebut semakin memperparah keadaan, kemudian disisi lain akan mengganggu aktivitas didalam melakukan pekerjaan. Pada cedera otot yang dilakukan diagnosa oleh dokter tahun 2018, dikatakan pada usia 15 tahun sampai dengan 24 tahun mengalami cedera otot dengan prosentase sebesar 1,2\%, kemudian pada usia 25 tahun sampai dengan 34 tahun dengan prosentase 3,1\% sampai dengan usia diatas lebih dari 75 tahun memiliki prosentase cedera otot sebesar 18,9\%. Disimpulkan dari usia 15 tahun sampai dengan diatas 75 tahun semua golongan usia memiliki risiko cedera otot dengan tingkat terbesar yaitu 18,9\% pada tabel dibawah ini.

Gambar 2. Cedera Otot Persendian Usia > 15 Tahun Diagnosis Dokter 2018

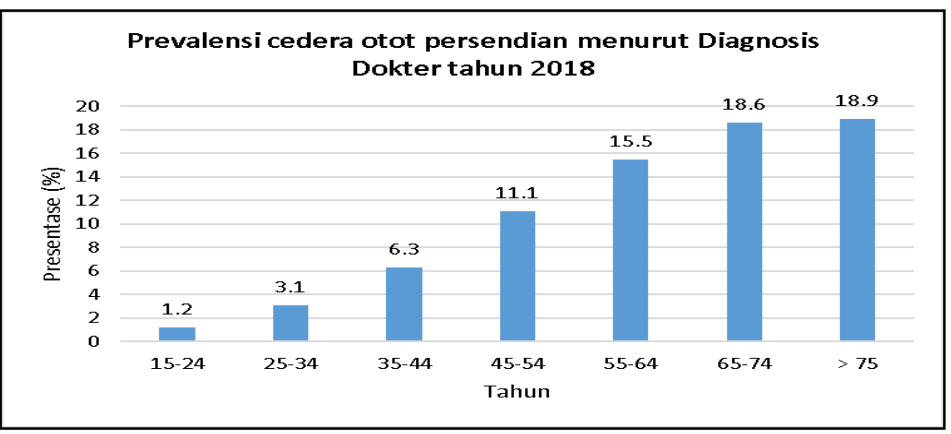


Cedera otot yang terjadi pada tenaga kerja di industri tahu, disebabkan karena melakukan aktivitas fisik yang diluar batas kekuatan tubuh [23]. Kekuatan tubuh tidak bisa dipaksa secara langsung, tetapi diperlukan pelatihan-pelatihan agar mampu melakukan pengangkatan beban yang berlebih agar bebas dari rasa sakit yang diakibatkan oleh cedera otot. Selain itu, kegiatan-kegiatan yang memang menimbulkan cedera otot perlu kehatihatian dalam melakukannya. Pada akhirnya, otot tubuh dipaksa untuk melakukan angkat beban berlebih tanpa adanya latihan pemanasan terlebih dahulu. Timbulnya stress kerja dan cedera otot juga memiliki kaitan dengan jumlah jam kerja ditiap harinya. Pada Agustus 2018 besarnya rata-rata jam kerja setiap minggunya adalah 44 jam pada tenaga kerja buruh, karyawan dan pegawai, karena sebelumnya jumlah rata-rata jam kerja sebesar 41 jam. Dalam hal ini, rata-rata jam kerja tersebut tanpa dihitung adanya jam lembur. Dari rata-rata jam kerja tersebut, jika diperlukan jam lembur dalam melakukan produksi tahu, maka dihitung dengan sistem gaji yang berbeda dan tambahan waktu disesuaikan dengan produksi yang sudah diasumsikan. Stress kerja dan cedera otot yang dialami oleh tenaga kerja akan memberikan dampat terhadap produktivitasnya [24]. Oleh karena itu, diperlukan cara-cara agar tenaga kerja mampu melakukan pengelolaan stress kerja agar tidak menimbulkan cedera otot demi meningkatkan produktivitas tenaga kerja di industri tahu [18], [25], [26]. Pengelolaan rasa stress perlu dilakukan secara baik, demi menghindari terganggunya didalam aktivitas kerja, selain itu tidak diperbolehkan membawa masalah stress kedalam luar aktivitas kerja. Karena, hal tersebut mampu membuat kegiatan lainnya bermasalah.

Terkait dengan stress kerja dan cedera otot dengan produktivitas tenaga kerja, akan dilakukan penelitian pada industri tahu yang berada pada daerah Kediri. Kegiatan yang berada pada industri tahu adalah melakukan proses produksi tahu dari awal yaitu biji kedelai dilakukan penghalusan sampai menjadi bubur kemudian diolah sampai menjadi tahu yang dipress menggunakan alat berat, bisanya digunakan batu yang beratnya hampir $5 \mathrm{~kg}$ agar proses pengepresan menjadi padat. Proses pengangkatan batu tersebut dilakukan berkalikali setiap harinya. Industri tahu tersebut dalam sekali pemasakan tahu melakukan 4 kali pengangkatan batu tersebut, jika satu hari dilakukan sampai 6 kali produksi maka sudah 24 kali proses angkat batu dilakukan. Oleh karena itu, dari pengangkatan batu tersebut akan menimbulkan cedera otot jika posisi kerja salah kemudian juga kan membuat pekerja terbebani jika terlalu banyak pemesanan tahu yang dilakukan. Tidak hanya pekerjaan angkat batu saja yang menibulkan cedera otot dan stress kerja, melainkan kegiatan-kegiatan yang lainnya juga memiliki potensi. Pekerja didalam satu industri tahu mayoritas adalah suami istri dibantu dengan satu sampai tiga pekerja, tetapi juga ada yang hanya suami istri saja. Diperlukan aktivitas-aktivitas yang memang dapat meminimalisir terjadinya cedera otot, selain itu semakin banyak pemesanan yang dilakukan oleh konsumen, industri tahu juga akan memperbanyak proses produksi setiap kali masakan tahu.

Dalam hal ini, penelitian bertujuan untuk mengetahui hubungan stress kerja dan cedera otor dengan produktivitas tenaga kerja. Batasan yang digunakan yaitu penelitian ini untuk mencari hubungan pada variabel stress kerja $\left(\mathrm{X}_{1}\right)$, variabel cedera otot $\left(\mathrm{X}_{2}\right)$ dan variabel produktivitas (Y). Asumsi yang digunakan dalam penelitian ini adalah tidak ada 
perubahan data yang sudah didapat pada observasi lapangan. Dalam penelitian ini digunakan hipotesis yaitu:

$\mathrm{H}_{0}$ : Tidak ada adanya hubungan stress kerja dengan produktivitas tenaga kerja.

$\mathrm{H}_{\mathrm{a}}$ : Adanya hubungan stress kerja dengan produktivitas tenaga kerja.

$\mathrm{H}_{0}$ : Tidak adanya hubungan cedera otot dengan produktivitas tenaga kerja. $\mathrm{H}_{\mathrm{a}}$ : Adanya hubungan cedera otot dengan produktivitas tenaga kerja.

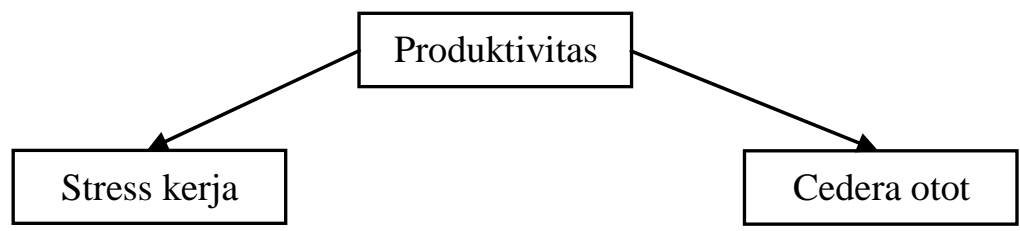

Gambar 3. Kerangka Berpikir

\section{Tinjauan Pustaka}

Pencapaian ergonomic perlu adanya keserasian antara pekerja dan pekerjaannya, sehingga manusia pekerja dapat bekerja sesuai dengan kemampuan, kebolehan, dan keterbatasannya. Secara umum kemampuan, kebolehan dan batasan manusia ditentukan oleh berbagai faktor yaitu : umur, jenis kelamin, ras, antropometri, status kesehatan, gizi, kesegaran jasmani, pendidikan, keterampilan, budaya, tingkah laku dan kebiasaan, kemampuan beradaptasi. Kapasitas kerja dapat dinilai dari kelelahan dan keluhan musculoskeletal [27]. Kelelahan merupakan suatu keadaan yang ditandai dengan adanya ketidakmampuan untuk mempertahankan kekuatan saat kontraksi otot secara berulang. Kelelahan ditandai dengan adanya kehilangan efisiensi, penurunan kapasitas kerja, dan ketahanan tubuh. Ada juga yang mendefinisikan kelelahan sebagai ketidakseimbangan kebutuhan dengan produksi ATP[26].

Ada dua jenis kelelahan, yaitu kelelahan sentral dan kelelahan perifer (Adrianto, 2014). Pada kelelahan sentralterjadi pengurangan frekuensi impuls dan jumlah motor unit yang terlibat. Kelelahan perifer berhubungan dengan faktor neural dan faktor mekanik. Faktor neural dihubungkan dengan kegagalan pada neuromuscular junction, sarkolema, ttubulus, atau retikulom sarkoplasma yang terlibat dalam penyimpanan, pelepasan, dan reuptake calsium. Kelelahan dapat dilihat pada sarkolemadan t-tubulusberupa adanya ketidakmampuan mempertahankan konsentrasi natrium dan kalium saat stimulasi berulang, akumulasi kalium ekstraseluler, berkurangnya amplitude aksi potensial, menurunnya fungsi t-tubulus,dan menurunnya pelepasan kalsium dari retikulom sarkoplasma. Faktor mekanik berhubungan dengan gangguan siklus cross-bridge, meningkatnya konsentrasi atau produksi asam laktat, berkurangnya ikatan kalsium dengan troponin, dan terhambatnya pelepasan kalsium oleh sarkoplasma reticulum.Pada kerja statis kontraksi otot meningkatkan tekanan pada otot yang bersangkutan. Peningkatan tekanan tanpa diikuti relaksasi menyebabkan oklusi pembuluh darah yang menyediakan zat nutrisi untuk otot yang bersangkutan. Pada keadaan ini, hanya terjadi perubahan sedikit pada curah jantung. Aliran darah ke bagian tersebut mulai berkurang, sehingga pembuangan zat sisa metabolism juga terhambat. Hal tersebutdapat mempercepat terjadinya kelelahan dan penurunan produktivitas kerja [26][27].

\section{Metode Penelitian}

\subsection{Tempat dan Waktu Penelitian}

Penelitian dilakukan pada industri tahu yang berada pada daerah Bulur, Kabupaten Kediri dengan durasi waktu penelitian mulai 8 Oktober 2018 sampai 
dengan 5 Januari 2018.

\subsection{Populasi dan Sampel}

\subsubsection{Populasi}

Terkait dengan obyek yang digeneralkan agar mampu memiliki kualitas dan suatu karakteristik sebuah obyek tertentu yang disebut sebagai populasi. Obyek tersebut ditetapkan oleh peneliti agar mampu ditarik kesimpulannya. Populasi yang digunakan adalah seluruh industri tahu di daerah Kabupaten Kediri.

\subsubsection{Sampel}

Sampel merupakan suatu bagian dari populasi yang mampu mewakili sebuah penelitian. Kegunaan sampel sebagai cara mengatasi kesulitan dalam penelitian jika terdapat populasi yang sulit dihitung atau terlalu banyak yang menghabiskan waktu yang lama [27]. Sampel yang digunakan industri tahu yang berada di daerah Bulur, Kabupaten Kediri.

\subsection{Metode Pengambilan Sampel Penelitian}

Didalam menentukan sampel pada penelitian, digunakan non-probability sampling dengan teknik purposive sampling [28], [29]. Didalam teknik ini memiliki kriteria yang terbagi menjadi 2 yaitu:

\subsubsection{Inklusi}

Inklusi adalah kriteria yang digunakan untuk mengambil sampel sesuai dengan tujuan penelitian. Maka, inklusi yang digunakan adalah:

a. Pernah mengalami stress kerja akibat pemesanan tahu yang berlebih dengan durasi $<14$ hari.

b. Pernah mengalami cedera otot pada saat bekerja membuat tahu dengan tingkat kesembuhan $<14$ hari.

c. Usia pekerja $>20$ tahun sampai $<80$ tahun.

\subsubsection{Eksklusi}

Eksklusi adalah kriteria dimana subjek penelitian tidak dapat mewakili sampel karena tidak memenuhi syarat sebagai sampel penelitian. Maka, eksklusi yang digunakan adalah:

a. Pernah mengalami stress kerja akibat pemesanan tahu yang berlebih dengan durasi $>14$ hari.

b. Pernah mengalami cedera otot pada saat bekerja membuat tahu dengan tingkat kesembuhan $>14$ hari.

Dari kriteria yang sudah diberikan, sampel penelitian berjumlah 17 tenaga kerja dengan kriteria sesuai dengan inklusi.

\subsection{Jenis dan Sumber Data}

Terkait dengan data yang digunakan sebagai berikut:

\subsubsection{Data Kuantitatif}

Data Kuantitatif adalah data yang diperoleh dari industri tahu terkait dengan tenaga kerja yang mengalami cedera otot dan stress kerja yang terjadi berapa kali disetiap bulannya dengan kriteria pada purposive sampling [30].

\subsubsection{Data Kualitatif}


Data Kualitatif adalah data yang didapat pada setiap industri tahu yang memenuhi teknik purposive sampling tentang stress kerja dan cedera otot yang dirasakan oleh pekerja berupa ungkapan lisan [31].

\subsubsection{Data Primer}

Data Primer yaitu data yang diperoleh langsung dari obyek penelitian dengan mengadakan pengamatan langsung atau wawancara pada tenaga kerja pembuat tahu agar bisa memperoleh data kuantitatif dan data kualitatif [32].

\subsubsection{Data Sekunder}

Data Sekunder yaitu data yang diperoleh secara tidak langsung melalui penelitian kepustakaan baik melalui dokumen-dokumen atau laporan tertulis serta informasi lainnya yang berhubungan dengan penelitian ini [32].

\subsection{Teknik Pengumpulan Data}

\subsubsection{Interview}

Interview merupakan suatu cara untuk mendapatkan data atau informasi dengan tanya jawab secara langsung pada orang yang mengetahui tentang obyek yang diteliti [33].

\subsubsection{Dokumentasi}

Dokumentasi adalah bentuk penelitian yang dilakukan dengan mengumpulkan dokumen atau arsip-arsip perusahaan yang berhubungan dengan masalah persediaan dalam bentik file [33].

\subsection{Skala Pengukuran}

Skala pengukuran merupakan kesempatan yang digunakan sebagai acuan untuk menentukan panjang pendekatan interval dalam alat ukur. Skala yang digunakan adalah skala Likert. Skala Likert digunakan untuk mengukur sikap, pendapat, dan persepsi seseorang atau sekelompok orang tentang fenumena sosial. Alat ukur ini bila digunakan dalam pengukuran akan menghasilkan data kuantitatif. Skala yang digunakan adalah skala Likert 1 sampai dengan 5 [34].

Tabel 2. Skala Pengukuran

\begin{tabular}{cc}
\hline Kategori & $\mathrm{S}$ \\
& $\mathrm{k}$ \\
& $\mathrm{O}$ \\
$\mathrm{r}$ & 5 \\
\hline Sangat Setuju & 4 \\
\hline Setuju & 3 \\
\hline Netral & 2 \\
\hline Tidak setuju & 1 \\
\hline Sangat Tidak & \\
Setuju &
\end{tabular}

\subsection{Definisi Operasional Variabel}

Definisi Operasional adalah penetuan konstrak atau sifat yang akan dipelajari sehingga menjadi variabel yang dapat diukur.

Tabel 3. Definisi Operasional Variabel

\begin{tabular}{|c|l|l|ll|c|}
\hline No. & Variabel & \multicolumn{2}{|c|}{ Definisi Operasional } & \multicolumn{1}{c|}{ Indikator } & Skala Ukur \\
\hline 1. & Stress & Perasaan yang & a. & Beban kerja adil dan wajar & Likert \\
& kerja (X1) & menekan atau merasa & b. & Sikap pemilik usaha adil dan wajar & \\
\hline
\end{tabular}




\begin{tabular}{|c|c|c|c|c|}
\hline & & $\begin{array}{l}\text { tertekan yang dialami } \\
\text { karyawan dalam } \\
\text { menghadapi pekerjaan } \\
{[35]}\end{array}$ & $\begin{array}{l}\text { c. Waktu bekerja adil dan wajar } \\
\text { d. Ada lemburan dilakukan istirahat dan } \\
\text { mencukupi asupan tubuh terlebih dahulu } \\
\text { e. Peralatan kerja memadai } \\
\text { f. Tidak ada konflik antara tenaga kerja } \\
\text { dengan pemilik usaha } \\
\text { g. Tidak ada masalah keluarga } \\
\text { h. Upah yang diberikan adil }\end{array}$ & \\
\hline 2. & $\begin{array}{l}\text { Cedera } \\
\text { otot (X2) }\end{array}$ & $\begin{array}{l}\text { Kondisi yang ditandai } \\
\text { dengan otot-otot serta } \\
\text { tendon pada otot yang } \\
\text { tertarik berlebihan } \\
\text { karena tekanan besar } \\
\text { yang disebabkan oleh } \\
\text { aktivitas fisik [21] }\end{array}$ & $\begin{array}{l}\text { a. Cedera area punggung } \\
\text { b. Cedera area lengan atas } \\
\text { c. Cedera area pinggang } \\
\text { d. Cedera area pundak } \\
\text { e. Istirahatkan tubuh waktu cedera } \\
\text { f. Berikan kompres es pada area cedera } \\
\text { g. Dilakukan pijatan perlahan pada area } \\
\text { cedera }\end{array}$ & Likert \\
\hline 3. & $\begin{array}{l}\text { Produktiv } \\
\text { itas kerja } \\
\text { (Y) }\end{array}$ & $\begin{array}{l}\text { Mampu menghasilkan } \\
\text { barang atau jasa sesuai } \\
\text { dengan diharapkan } \\
\text { dalam waktu yang } \\
\text { singkat atau tepat [36] }\end{array}$ & $\begin{array}{l}\text { a. Pekerjaan yang dibebankan sesuai porsi } \\
\text { b. Berusaha meningkatkan kualitas kerja } \\
\text { c. Terkadang mengalami jenuh } \\
\text { d. Beban kerja berlebih menyebabkan stress } \\
\text { kerja } \\
\text { e. Sering angkat benda berat menyebabkan } \\
\text { cedera otot }\end{array}$ & Likert \\
\hline
\end{tabular}

\subsection{Metode Analisis}

Metode analisis yaitu metode yang digunakan untuk membuat gambaran secara sistematis, faktual dan akurat mengenai topik pada penelitian yaitu menggunakan Analisis Chi-Square. Di dalam analisis ini pengambilan keputusan sebagai berikut [37], [7]:

3.8.1 Berdasarkan nilai Asymp. Sig variabel < 0,05 dinyatakan ada hubungan antara variabel $\mathrm{X}$ dengan $\mathrm{Y}$.

3.8.2 Berdasarkan Chi - Square tabel < Chi-Square Hitung dinyatakan ada hubungan antara variabel $\mathrm{X}$ dengan $\mathrm{Y}$.

\section{Hasil Pembahasan}

Didalam deskripsi responden yang berjumlah 17 tenaga kerja pada industri tahu di Bulur, Kabupaten Kediri dengan deskripsi sebagai berikut:

Tabel 4. Deskripsi Usia Responden

\begin{tabular}{|c|c|c|c|}
\hline \multicolumn{4}{|c|}{ Usia } \\
\hline & & kuensi & Prosentase (\%) \\
\hline \multirow[t]{11}{*}{ Valid } & 43 & 2 & 11.8 \\
\hline & 45 & 1 & 5.9 \\
\hline & 46 & 1 & 5.9 \\
\hline & 48 & 1 & 5.9 \\
\hline & 49 & 1 & 5.9 \\
\hline & 53 & 2 & 11.8 \\
\hline & 55 & 1 & 5.9 \\
\hline & 56 & 1 & 5.9 \\
\hline & 57 & 1 & 5.9 \\
\hline & 58 & 1 & 5.9 \\
\hline & 64 & 1 & 5.9 \\
\hline
\end{tabular}




\begin{tabular}{|c|c|c|}
\hline 65 & 1 & 5.9 \\
\hline 66 & 2 & 11.8 \\
\hline 67 & 1 & 5.9 \\
\hline Total & 17 & 100.0 \\
\hline
\end{tabular}

Dari deskripsi usia pada responden yang berjumlah 17 orang memiliki usia 43, 53 dan 66 tahun berjumlah 2 orang, sedangkan pada usia 45, 46, 48, 49, 55, 56, 57, 58, 64,65 dan 67 tahun masing- masing berjumlah 1 orang.

Tabel 5. Hubungan Stress Kerja dengan Produktivitas

\begin{tabular}{ccc}
\hline & \multicolumn{2}{c}{ Test Statistics } \\
\hline Stress kerja $(\mathrm{X} 1)$ & Produktivitas (Y) \\
\hline Chi-Square & $19.000^{\mathrm{a}}$ & $9.941^{\mathrm{b}}$ \\
\hline $\mathrm{df}$ & 3 & 1 \\
\hline Asymp. Sig. & .000 & .002 \\
\hline
\end{tabular}

a. 4 cells (100.0\%) have expected frequencies less than 5. The minimum expected cell frequency is 4.3 .

b. 0 cells $(0.0 \%)$ have expected frequencies less than 5. The minimum expected cell frequency is 8.5 .

(Sumber: Olah Data, 2020)

Pada perhitungan menggunakan uji Chi-Square variabel stress kerja dengan produktitas memiliki nilai Asymp. Sig sebesar 0,000 dan 0,002 yang dimana nilai tersebut $<$ alpha $(0,05)$. Didalam nilai df pada variabel Stress kerja sebesar 3 menggunakan prosentase alpha sebesar 0,05 disimpulkan titik presentase adalah 7,81473, dengan nilai ChiSquare hitung sebesar 19,000. Kemudian dibandingkan nila df pada variabel produktivitas yaitu 1 dengan prosenstase alpha 0,05 didapatkan Chi-Square tabel sebesar 3,84146 dibandingkan dengan Chi-Square hitung sebesar 9,941. Didalam hal ini hipotesis yang sudah dibuat sebagai berikut:

$\mathrm{H}_{0}$ : Tidak ada adanya hubungan stress kerja dengan produktivitas tenaga kerja.

$\mathrm{H}_{\mathrm{a}}$ : Adanya hubungan stress kerja dengan produktivitas tenaga kerja

Maka, hipotesis yang didapatkan $\mathrm{H}_{0}$ ditolak dan $\mathrm{H}_{\mathrm{a}}$ diterima. Jadi, ada hubungan pada variabel stress kerja dengan produktivitas. Hubungan kedua variabel tersebut sangat signifikan dibuktikan dengan nilai Asymp. Sig variabel stress kerja sebesar 0,000 sudah mencapai nilai $0,000<0,05$ dan variabel produktivitas sebesar $0,002<0,05$.

Tabel 6. Hubungan Cedera Otot dengan Produktivitas

\begin{tabular}{ccc}
\hline & \multicolumn{2}{c}{ Test Statistics } \\
\hline & Cedera otot $(\mathrm{X} 2)$ & Produktivitas (Y) \\
\hline Chi-Square & $24.176^{\mathrm{a}}$ & $9.941^{\mathrm{b}}$ \\
\hline $\mathrm{df}$ & 3 & 1 \\
\hline Asymp. Sig. & .000 & .002 \\
\hline
\end{tabular}

a. 4 cells (100.0\%) have expected frequencies less than 5. The minimum expected cell frequency is 4.3 .

b. 0 cells $(0.0 \%)$ have expected frequencies less than 5. The minimum expected cell frequency is 8.5 .

(Sumber: Olah Data, 2020) 
Pada perhitungan menggunakan uji Chi-Square variabel cedera otot dengan produktitas memiliki nilai Asymp. Sig sebesar 0,000 dan 0,002 yang dimana nilai tersebut $<$ alpha $(0,05)$. Didalam nilai df pada variabel Stress kerja sebesar 3 menggunakan prosentase alpha sebesar 0,05 disimpulkan titik presentase adalah 7,81473, dengan nilai ChiSquare hitung sebesar 24176. Kemudian dibandingkan nila df pada variabel produktivitas yaitu dengan prosentase alpha 0,05 didapatkan Chi-Square tabel sebesar 3,84146 dibandingkan dengan Chi-Square hitung sebesar 9,941. Didalam hal ini hipotesis yang sudah dibuat sebagai berikut:

$\mathrm{H}_{0}$ : Tidak ada adanya hubungan cedera otot dengan produktivitas tenaga kerja. $\mathrm{H}_{\mathrm{a}}$ : Adanya hubungan cedera otot dengan produktivitas tenaga kerja

Maka, hipotesis yang didapatkan $\mathrm{H}_{0}$ ditolak dan $\mathrm{H}_{\mathrm{a}}$ diterima. Jadi, ada hubungan pada variabel cedera otot dengan produktivitas. Hubungan kedua variabel tersebut sangat signifikan dibuktikan dengan nilai Asymp. Sig variabel stress kerja sebesar 0,000 sudah mencapai nilai $0,000<0,05$ dan variabel produktivitas sebesar $0,002<0,05$.

\section{Kesimpulan dan Saran}

Dari hasil penelitian yang dilakukan pada industri tahu di daerah Bulur, Kabupaten Kediri pada perumusan masalah yang diambil sesuai dengan tujuan penelitian sebagai berikut, Adanya hubungan pada stress kerja dengan produktivitas kerja yang dibuktikan dengan nilai hubungan kurang dari nilai prosentase dan hampir mendekati nilai signifikan serta hipotesis yang sudah dibuat. Adanya hubungan pada cedera otot dengan produktivitas kerja dibuktikan dengan nilai hubungan kurang dari nilai prosentase dan hampir mendekati nilai signifikan serta hipotesis yang sudah dibuat.

\section{Daftar Pustaka}

[1] Bekraf, "Kegiatan BEKRAF dan BPS Rilis Buku Statistik Ekonomi Kreatif," bekraf.go.id. .

[2] UKMIndonesia, "Potret UMKM Indonesia: Si Kecil yang Berperan Besar," https://www.ukmindonesia.id/, 2019. [Online]. Available: https://www.ukmindonesia.id/. [Accessed: 19-Jan-2019].

[3] M. by Mekar, "Perbedaan UMKM Perkembangannya di Indonesia," jurnal.id, 2017. [Online]. Available: https://www.jurnal.id/id/blog/2017-perbedaan-umkmperkembangannya-di-indonesia/. [Accessed: 17-Jan-2020].

[4] Supriyanto, "Pemberdayaan Usaha Mikro, Kecil dan Menengah (UMKM) Sebagai Salah Satu Upaya Penanggulangan Kemiskinan," J. Ekon. dan Pendidik., vol. 3, no. 1, pp. 1-16, 2012.

[5] T. K. Rohmah, "Miris! Serap Tenaga Kerja Paling Banyak, UMKM Masih Abaikan Kesehatan dan Keselamatan Kerja (K3)," https://www.kompasiana.com/, 2019. [Online]. Available: https://www.kompasiana.com/trikurniarohmah/5dcd0ac4d541df22a41ede62/mirisserap-tenaga-kerja-paling-banyak-umkm-masih-abaikan-kesehatan-dan- 
keselamatan-kerja-k3?page=all. [Accessed: 19-Jan-2020].

[6] S. Rahayuningsih and J. A. Pradana, "Identifikasi Penerapan Dan Pemahaman Kesehatan Dan Keselamatan Kerja Dengan Metode Hazard And Operability Study (Hazop) Pada UMKM Eka Jaya," JATI UNIK J. Ilm. Tek. dan Manaj. Ind., vol. 2, no. 1, p. 20, 2019.

[7] C. Jin, T. Ma, and R. Hou, "Chi-SquareStatistics Feature Selection Based on Term Frequency and Distribution for Text Categorization," IETE J. Reserach, vol. 61, no. 4, 2015.

[8] Y. Chen, B. McCabe, and D. Hyatt, "Impact of individual resilience and safety climate on safety performance and psychological stress of construction workers: A case study of the Ontario construction industry," J. Safety Res., vol. 61, pp. 167-176, 2017.

[9] A. Singh, M. Arora, V. Harma, and A. Kotwal, "Stress: Prevalence and correlates among residents of a suburban area," Ind. Psychiatry J., vol. 28, no. 1, pp. 98-102, 2019.

[10] B. A. Putri, "The Correlation between Age, Years of Service, and Working Postures and the Complaints of Musculoskeletal Disorders," Indones. J. Occup. Saf. Heal., vol. 8, no. 2, p. 187, 2019.

[11] D. P. Restuputri, T. Baroto, and P. Eka, "Analisis Postur Kerja Terkait Musculoskeletal Disorders (MSDS) pada Pengasuh Anak," Tek. Ind. Univ. Muhammadiyah Malang, vol. Prosiding, 2017.

[12] H. dan Y. Iridiastadi, Ergonomi Suatu Pengantar, 4th ed. Bandung: PT. Remaja Rosdakarya, 2017.

[13] S. M. W. Wadya, "Ergonomi dalam Lingkungan Kerja," VEDC Malang, 2016. [Online]. https://www.vedcmalang.com/pppptkboemlg/index.php/baru/44-mesin-cnc/1129sonnym. [Accessed: 07-Jul-2019].

[14] R. D. Rahmayani, R. G. Liza, and N. A. Syah, "Gambaran Tingkat Stres Berdasarkan Stressor pada Mahasiswa Kedokteran Tahun Pertama Program Studi Profesi Dokter Fakultas Kedokteran Universitas Andalas Angkatan 2017,' J. Kesehat. Andalas, vol. 8, no. 1, p. 103, 2019.

[15] S. Mustaffa, R. Aziz, M. N. Mahmood, and S. Shuib, "Depression and Suicidal Ideation among University Students," Procedia - Soc. Behav. Sci., vol. 116, pp. 42054208, 2014.

[16] F. Wajdi and W. Kusmasari, "Resiko jenis pekerjaan terhadap keluhan Msds pada perawat RSUD Serang Banten,” Tek. Ind. UMJ Jakarta, no. November 2015, pp. 17, 2015.

[17] S. T. Yang, M. H. Park, and B. Y. Jeong, "Types of manual materials handling 
$(\mathrm{MMH})$ and occupational incidents and musculoskeletal disorders (MSDs) in motor vehicle parts manufacturing (MVPM) industry," Int. J. Ind. Ergon., vol. 77, p. 102954, 2020.

[18] Lusia Salmawati, Sumarni DW, and Soebijanto, "the Association Between Implementation of Occupational Health and Safety Management System, Work Motivation and Occupational Stress Among Nurses At Anutapura General Hospital, Palu," $\square$ J. Manaj. Pelayanan Kesehat., vol. 18, no. 1, pp. 4-6, 2015.

[19] I. Sumaiya Thaseen and C. Aswani Kumar, "Intrusion detection model using fusion of Chi-Squarefeature selection and multi class SVM," J. King Saud Univ. - Comput. Inf. Sci., vol. 29, no. 4, pp. 462-472, 2017.

[20] S. Lahitani, "7 Pekerjaan di 2015 dengan Tingkat Stres Tertinggi," liputan6.com, 2015. [Online]. Available: https://www.liputan6.com/citizen6/read/2167122/7pekerjaan-di-2015-dengan-tingkat-stres-tertinggi. [Accessed: 06-Feb-2020].

[21] R. Ginting and A. F. Malik, "Analisis Keluhan Rasa Sakit Yang Dialami Pekerja Pada Ukm Sepatu Kulit Di Kota Dengan Menggunakan Kuesioner SNQ," J. Sist. Tek. Ind., vol. 18, no. 1, pp. 15-19, 2018.

[22] A. Thetkathuek, P. Meepradit, and T. Sa-Ngiamsak, "A Cross-sectional Study of Musculoskeletal Symptoms and Risk Factors in Cambodian Fruit Farm Workers in Eastern Region, Thailand," Saf. Health Work, vol. 9, no. 2, pp. 192-202, Jun. 2018.

[23] D. Mayasari and F. Saftarina, "Ergonomi sebagai Upaya Pencegahan Musculoskeletal Disorders pada Pekerja," JK Unila, 2016.

[24] M. D. Angelica et al., "Determinants of Time Allocation across the Lifespan A Theoretical Model and an Application to the," PLoS One, 2012.

[25] G. Naik and M. R. Khan, "Prevalence of MSDs and Postural Risk Assessment in Floor Mopping Activity Through Subjective and Objective Measures," Saf. Health Work, vol. 11, no. 1, pp. 80-87, 2020.

[26] L. T. Dewi, "Karakterisasi Keluhan Muskuloskeletal Akibat Postur Kerja Buruk Pada Pekerja Industri Kecil Makanan,” J. Ilm. Tek. Ind., vol. 15, no. 2, p. 145, 2017.

[27] Salamadian, "Definisi Sampel Penelitian," salamadian, 2020. .

[28] I. Etikan, "Comparison of Convenience Sampling and Purposive sampling," Am. J. Theor. Appl. Stat., 2016.

[29] E. Rinaldi, W. Utomo, and F. A. Nauli, "Hubungan Posisi Kerja Pada Pekerja Industri Batu Bata Dengan Kejadian Low Back Pain," Progr. Stud. Ilmu Keperawatan Univ. Riau, vol. 22, no. 1, pp. 9-18, 2015.

[30] M. P. Dr. Whidmurni, "Penelitian Kuantitatif," Pemaparan Metod. Kuantitatif, 2017.

[31] P. D. Sugiyono, metode penelitian kuantitatif, kualitatif,dan R\&D. 2016. 
[32] Ali Maksum, "Data, Teknik Pengumpulan Data dan Instrumen Penelitian," $J$. Cakrawala Kependidikan, no. agustus, p. 107, 2012.

[33] Sugiyono, "Teknik Pengumpulan Data," Metod. Penelit. Kuantitatif, Kualitatif dan $R \& D$, p. 137, 2014.

[34] W. Budiaji, “Skala Pengukuran dan Jumlah Respon Skala Likert,” J. Ilmu Pertan. dan Perikan., 2013.

[35] T. Bianchi, M. Belingheri, A. Nespoli, G. De Vito, and M. A. Riva, "Occupational Risks in Midwifery: From Bernardino Ramazzini to Modern Times," Saf. Health Work, vol. 10, no. 2, pp. 245-247, 2019.

[36] D. Agung, F. Debora, and H. H. Purba, "Increased Productivity of Injection Molding with Analysis of Overall Equipment Effectiveness ( OEE )," Int. J. Res. Eng. Sci. Manag., vol. 1, no. 12, pp. 1-7, 2018.

[37] R. Rakesh and R. Singhal, "Chi-Squaretest and its application in hypothesis testing," J. Pract. Cardiovasc. Sci., vol. 1, no. 1, pp. 69-71, 2015. 